\title{
Serum calcium ions, ratio of calcium/ creatinine urine and bone mass density in perimenopausal and postmenopausal women
}

\author{
Riswan Hadi Kusuma ${ }^{*}$, Windarwati ${ }^{2}$, Harjo Mulyono ${ }^{2}$ \\ ${ }^{1}$ Academic Hospital, UGM, ${ }^{2}$ Department of Patology Clinic, Faculty of Medicine, \\ Universitas Gadjah Mada, Yogyakarta
}

\begin{abstract}
Early diagnosis of osteoporosis is important to take early prevention and treatment. Dual energy $X$-ray absorbtiometry (DEXA) scan is gold standard diagnosis of osteoporosis. However, it is high technology and high cost. Biochemical marker using calcium could be developed for diagnosis of osteoporosis. The study was conducted to evaluate the correlation between serum calcium ions level as well as urine calcium and urine creatinine $(\mathrm{UCa} / \mathrm{UCr}$ ) ratio and Bone Mineral Density (BMD) in perimenopausal and postmenopausal women. This was an observational study with cross-sectional design involving women aged 45-75 years who fulfilled the inclusion and exclusion criteria. Bone Mineral Density was measured using DEXA method. Serum and urine calcium ions were measured using ISE method, while serum and urine creatinine were determined using Jaffe method. Ratio of $\mathrm{UCa} / \mathrm{UCr}$ were then calculated. The correlation between serum calcium ions as well as the ratio $\mathrm{UCa} / \mathrm{UCr}$ and $\mathrm{BMD}$ of subjects were then analyzed. A total 63 subjects were involved in this study consists of 21 normal subjects, 22 subjects with osteopenia and 20 subjects with osteoporosis. Negative correlation between BMD and age $(r=-0.591 ; p=0.001)$ and positive correlation between $B M D$ and body mass index (BMI) $(r=0.432 ; p=0.001)$ were observed. No correlation between serum calcium ions and BMD $(r=-0.145 ; p=0.258)$, however negative correlation between UCa/UCr ratio and BMD $(r=-0.310 ; p=0.013)$ were reported. Furthermore, no correlation was found between serum calcium ions and lumbar BMD $(r=0.036$; $\mathrm{p}=0.778)$, while negative correlation was found between $\mathrm{UCa} / \mathrm{UCr}$ ratio and lumbar BMD $(r=-$ $0.414 ; p=0.001)$. In conclusion, there is no correlation between serum calcium ions levels and $\mathrm{BMD}$, however there is a weak negative correlation between $\mathrm{UCa} / \mathrm{UCr}$ ratio and BMD.
\end{abstract}

\section{ABSTRAK}

Diagnosis dini osteoporosis penting untuk melakukan tindakan pencegahan dan pengobatan sedini mungkin. Skaning Dual-energy $X$-ray absorbtiometry (DEXA) merupakan diagnosis standar emar osteoporosis. Namun demikian, metode ini perlu teknologi tinggi dan biaya mahal. Marker biokimia kalsium kemungkinan dapat dikembangkan untuk diagnosis osteoporosis. Penelitian ini dilakukan untuk mengkaji hubungan antara kadar ion kalsium serum dan juga rasio kalsium urin/ kreatinin urin (UCa/UCr) dan Densitas Mineral Tulang (Bone Mineral Density/BMD) pada wanita perimenopause dan post menopause. Penelitian ini merupakan penelitian observational dengan rancangan potong lintang yang melibatkan wanita berumur 45-75 tahun yang memenuhi kriteria inklusi dan eksklusi. Ion kalsium urin dan serum ditetapkan dengan metode ISE, sedangkan kreatinin serum dan urin dengan metode Jaffe untuk menghitung rasio UCa/UCr. Hubungan antara ion kalsium serum dan juga juga rasio $\mathrm{UCa} / \mathrm{UCr}$ dengan BMD selanjutnya dievaluasi. Dari total 63 subjek yang terlibat terdiri dari 21 subjek normal, 22 subjek mengalami osteopenia dan 20 subjek mengalami osteoporosis. Terdapat hubungan negatif BMD dan umur $(r=-0,591$;

\footnotetext{
* corresponding author: riswanhk@yahoo.com
} 
$p=0,001)$ dan hubungan positif antara BMD dan indeks masa tubuh (IMT) $((r=0,432 ; p=0,001)$. Tidak terdapat hubungan antara ion kalsium serum dan BMD $(r=-0,145 ; p=0,258)$, namun terdapat hubungan negatif antara rasio $U C a / U C r$ dan BMD $(r=0,310 ; p=0,013)$. Selanjutnya terbukti tidak ada hubungan antara ion kalsium serum dan BMD lumbal $(r=0.036 ; p=0,778)$, namun demikian terdapat hubungan negatif antara rasio $\mathrm{UCa} / \mathrm{UCr}$ dan $B M D$ lumbal $(r=-0,414$; $\mathrm{p}=0,001)$. Dapat disimpulkan, tidak terdapat hubungan antara kadar ion kalsium serum dengan $B M D$, namun terdapat hubungan negatif lemah antara rasio $\mathrm{UCa} / \mathrm{UCr}$ dengan BMD.

Keywords: osteoporosis - calcium ions - serum - urine - DEXA

\section{INTRODUCTION}

The increase of life expectancy and the lack of knowledge concerning osteoporosi prevention leads to the high risk of osteroporosis of women population in Indonesia. ${ }^{1}$ Osteoporosis is defined as a systemic bone disease characterized by low bone mass density (BMD) and microarchitectural deterioration of bone tissue, leading to enhanced bone fragility and a consequent increase in fracture risk..$^{2,3}$ The prevalence of osteoporosis is growing, especially as the number of postmenopausal women in the population continues to rise. An estimated 52 million women aged fifty years plus are expected to be affected by osteoporosis and osteopenia by 2010 and 61 million are expected to be affected by $2020 .^{4}$

Concern has been addressed recently about the early screening of osteoporosis in perimenopausal and postmenopausal women. This early screening is important to take action about early prevention and treatment of the osteoporosis. Several osteoporosis examinations including radiological, biopsy and biochemical examinations have been developed base on reduction of BMD in the osteoporosis. ${ }^{3,5}$ Radiological examination to assess BMD with dual X-ray method absorbtiometry (DEXA) is the gold standard for diagnosing osteoporosis. ${ }^{6}$ However, the radiological examination needs high technology and cost. Therefore, it can not be applied in all health care centers. Whereas, the biopsy examination is too invasive and the results on one part of skeleton cannot be applied to the other skeleton. ${ }^{7}$

In order to obtain an effective and efficient method, several biochemical markers reflecting a bone state or bone remodeling process have being developed for diagnosing osteoporosis. Calcium, well known as a bone resorption marker, is recommended as biochemical marker for osteoporosis screening. Three forms of calcium exist in the blood i.e. calcium ions, protein-bound calcium and complex-bound calcium. The serum calcium ions is the active form reflecting physiological and pathological conditions of the body. ${ }^{8,9}$

This study was conducted to evaluate the correlation between serum calcium ions level and BMD in perimenopausal and postmenopausal women. The correlation between ratio of urine calcium and urine creatinine (UCa/UCr) for 24-hour urinary excretion was also evaluated. This $\mathrm{UCa} / \mathrm{UCr}$ ratio can be used to estimate the mean calcium excretion in the urine. ${ }^{10,11}$

\section{MATERIALS AND METHODS}

\section{Subjects}

This was an observational study with crosssectional design conducted in the Integrated Services Post of Elderly (Pos Pelayanan Terpadu Lanjut Usia/Posyandu Lansia) in Kalangan Village, Banguntapan Sub-district, Bantul District from June to July 2010. Subjects of study were women aged 45-75 years who 
fulfilled the inclusion and exclusion criteria. The inclusion criteria were perimenopausal and postmenopausal women, while the exclusion criteria were patients with a history of malignancy, underwent chemotherapy or radiation therapy, had renal failure or renal dysfunction (serum creatinine $\geq 1.3 \mathrm{mg} / \mathrm{dL}$ or creatinine clearance $<88 \mathrm{~mL} /$ minute $/ 1.73 \mathrm{~m} 2$ or urine creatinine levels low/high), had metabolic bone and joint diseases, history of surgical removal of the ovaries, underwent a hormone replacement therapy (HRT) and unable to collect samples of serum and urine appropriatly. The study would be conducted after obtained approval from the Medical and Health Research Ethics Committee, Faculty of Medicine, Universitas Gadjah Mada, Yogyakarta.

\section{Procedure of study}

On the day when study started, subjects were consecutively selected. An explanation concerning the background, objectives and benefits of the study was given. Subjects who fulfilled the inclusion and exclusion criteria were given an informed consent to be signed. Anamnesis was then performed to gather informations of subject characteristics. Physical examination including body weight and body height measurement, Body Mass Index (BMI) calculation was also conducted. Bone Mineral Density (BMD) examination was conducted followed by serum and urine ionized calcium examination as well as serum and urine creatinine examination. Ratio of urine calcium and urine creatinine ( $\mathrm{UCa} / \mathrm{UCr}$ ) were then calculated. The correlation between serum calcium ions and the ratio $\mathrm{UCa} / \mathrm{UCr}$ with $\mathrm{BMD}$ of subjects was analyzed.

The BMD measurement to diagnose the osteoporosis of women subjects was conducted in Department of Radiology, Dr. Sardjito General Hospital using a dual-energy X-ray absorptiometry (DEXA) scan. The BMD value obtained was used to calculate $T$ scores which used to evaluate degree of osteoporosis of the subjects according to World Health Organization criteria (TABLE 1).

TABLE 1. Diagnosis of osteroporosis based on BMD value

\begin{tabular}{|c|c|}
\hline Diagnostic category & Criterion \\
\hline Normal & $\begin{array}{l}\text { A BMD val ue that is within } 1.0 \mathrm{SD} \text { (standard deviation) of the } \\
\text { reference mean for healthy women }\end{array}$ \\
\hline Osteopenia & $\begin{array}{l}\text { A BMD value that is more than } 1.0 \text { but less than } 2.5 \text { SD below the } \\
\text { mean for healthy women }\end{array}$ \\
\hline Osteoporosis & $\begin{array}{l}\text { A BMD value that is } 2.5 \mathrm{SD} \text { or more below the mean for healthy } \\
\text { women }\end{array}$ \\
\hline Scverc ostcoporosis & $\begin{array}{l}\text { A BMD value that is } 2.5 \mathrm{SD} \text { or more below the mean for healthy } \\
\text { women in combination with onc or morc fragility (low-trauma) } \\
\text { fractures }\end{array}$ \\
\hline
\end{tabular}

Serum and urine calcium ions were measured using ISE method in the Clinical Laboratory Installation, Dr. Sardjito General Hospital using a Beckman Coulter Synchron chemistry Analyzer CX Pro. Subject fasted for 10 hours before serum and urine sample were taken. No vigorous physical activities were suggested during fasting. Drinking water $a d$ 
libitum was provided to subjects. Serum and urine creatinine were measured using Jaffe method in the same laboratory. Assessment of renal function was performed using serum creatinine levels or creatinine clearance or urine creatinine using the Cockcroft-Gault formula.

\section{Statistical analysis}

Diagnostic performance tests including calibration, precision and accuracy was conducted for each measurement method. The precision of measurement method was expressed by mean, standard deviation (SD) and calculated the coefficient of variation (CV) value, whereas the accuracy was expressed by the closeness of a measured value to a standard or true value. Statistical analysis used were the Kolmogorov-Smirnov, Chi-square, one-way Anova and Pearson correlation. Value of $\mathrm{p}<$ 0.05 with $95 \%$ Confidence Interval $(95 \%$ CI) was considered as statistically significant.

\section{RESULS}

\section{Characteristics of subjects}

Sixty-three eligible subjects were involved in this study. The characteristics of subjects are presented in TABLE 2.

TABLE 2. Characteristics of subjects

\begin{tabular}{lcc}
\hline Variables & $\mathrm{n}$ & $\%$ \\
\hline Age (year) & & \\
• $45-54$ & 25 & 39.7 \\
- $55-64$ & 21 & 33.3 \\
• $>65$ & 17 & 27 \\
BMI & & \\
• $\quad 25$ & 32 & 50.8 \\
• $\geq 25$ & 31 & 49.2 \\
Menopausal status & & \\
- Perimenopause & 21 & 33.3 \\
- Postmenopause & 42 & 66.7 \\
History of fracture & & \\
• Yes & 4 & 6.3 \\
- No & 59 & 93.7 \\
\hline
\end{tabular}

TABLE 2. Characteristics of subjects (lanjutan

\begin{tabular}{lcc}
\hline Variables & $\mathrm{n}$ & $\%$ \\
\hline Milk consumption & & \\
- Never & 59 & 93.7 \\
- Some time - frequent & 4 & 6.3 \\
Calcium suplement & & \\
- Never & 38 & 60.3 \\
- Some time - frequent & 25 & 39.7 \\
Corticosteroid consumption & & \\
- Yes & 4 & 6.3 \\
- No & 59 & 93.7 \\
Physical activities & & \\
- Mild & 20 & 31.7 \\
- Moderate-vigorous & 43 & 68.3 \\
\hline
\end{tabular}

\section{The status of BMD of subjects}

The BMD status of subjects risk factors of osteoporosis is presented in TABLE 3. BMD examination was performed on hip and lumbar regions. The BMD value was then used to determine T-score which would be used to determine osteoporosis status of subjects based on WHO criteria. Among 63 subjects who examined, 21 (33.3\%) subjects had normal BMD, 22 (34.9\%) had osteopenia and 20 subjects $(31.7 \%)$ subjects had osteoporosis.

Age, BMI and menopausal status were significantly associated with osteroporosis status subjects $(p<0.05)$. The incidence of osteoporosis was found higher in older age group than the younger groups. Subjects with low BMI more likely to have osteoporosis than those with high BMI. Moreover, postmenopausal women had higher risk of osteoporosis than perimenopausal ones. Conversly, history of fracture, milk consumption, calcium suplement, corticosteroid consumption and physical activities were not significantly associated with osteoporosis status of subjects $(\mathrm{p}>0.05)$. 
Kusuma et al., Correlation between serum calcium ions, ratio of calcium/creatinine urine and bone mass density in perimenopausal and postmenopausal women

TABLE 3. Status of BMD of subjects based on risk factors of osteoporosis

\begin{tabular}{|c|c|c|c|c|}
\hline Variables & $\begin{array}{c}\text { Normal } \\
(\mathrm{n}=21)\end{array}$ & $\begin{array}{c}\text { Osteoponia } \\
(n=22)\end{array}$ & $\begin{array}{c}\text { Osteoporosis } \\
(\mathrm{n}=20)\end{array}$ & $\mathrm{p}$ \\
\hline \multicolumn{5}{|l|}{ Age (year) } \\
\hline - $45-54$ & 14 & 11 & 0 & \multirow{3}{*}{0.001} \\
\hline - $55-64$ & 6 & 8 & 7 & \\
\hline - $>65$ & 1 & 3 & 13 & \\
\hline \multicolumn{5}{|l|}{ BMI } \\
\hline - $<25$ & 7 & 9 & 16 & \multirow{2}{*}{0.006} \\
\hline - $=25$ & 14 & 13 & 4 & \\
\hline \multicolumn{5}{|l|}{ Menopausal status } \\
\hline - Perimenopause & 13 & 8 & 0 & \multirow{2}{*}{0.001} \\
\hline - Postmenopause & 8 & 14 & 20 & \\
\hline \multicolumn{5}{|l|}{ History of fracture } \\
\hline - Ycs & 1 & 2 & 1 & \multirow{2}{*}{0.807} \\
\hline - No & 20 & 20 & 9 & \\
\hline \multicolumn{5}{|l|}{ Milk consumption } \\
\hline - Never & 20 & 20 & 19 & \multirow{2}{*}{0.807} \\
\hline \multicolumn{4}{|l|}{ Calcium suplement } & \\
\hline - Never & 12 & 14 & 12 & \multirow{2}{*}{0.909} \\
\hline - Some time - frequent & 9 & 8 & 8 & \\
\hline \multicolumn{5}{|l|}{ Corticosteroid consumption } \\
\hline - Yes & 0 & 2 & 2 & \multirow{2}{*}{0.341} \\
\hline - No & 21 & 30 & 18 & \\
\hline \multicolumn{5}{|l|}{ Physical activities } \\
\hline - Mild & 5 & 7 & 8 & \multirow{2}{*}{0.538} \\
\hline - Moderate-vigorous & 16 & 15 & 12 & \\
\hline
\end{tabular}

* One way Anova (significant different if $p<0.05$ )

Further analysis showed that there was a negative correlation between $\mathrm{BMD}$ and age $(\mathrm{r}=$ between BMD and BMI $(\mathrm{r}=0.432 ; \mathrm{p}=0.001)$ as $-0.591 ; p=0.001)$ and positive correlation presented in TABLE 4.

TABLE 4. Correlation between BMD status and age or BMI

\begin{tabular}{lcc}
\hline Variables & $\mathrm{r}$ & $\mathrm{p}^{*}$ \\
\hline BMD status versus age & -0.591 & 0.001 \\
BMD status versus BMI & 0.432 & 0.001 \\
\hline
\end{tabular}

*Pearson correlation test (significant different if $p<0.05$ )

\section{Serum calcium ions of subjects}

The mean of serum calcium ions levels and the ratio of $\mathrm{UCa} / \mathrm{UCr}$ based on the risk factors of osteoporosis is presented in TABLE 5 and 6. No significantly difference was observed in serum calcium ions levels and in the ratio of
$\mathrm{UCa} / \mathrm{UCr}$ based on the risk factors osteoporosis namely age, BMI, menopausal status, history of fracture, milk consumption, calcium supplements, and corticosteroid consumption as well as physical activities ( $\mathrm{p}>0.05)$. 
TABLE 5. Mean of serum calcium ions $(\mathrm{mg} / \mathrm{dL})$ based on the risk factors of osteoporosis

\begin{tabular}{|c|c|c|c|}
\hline Variables & $\mathrm{n}=63$ & $\begin{array}{l}\text { Calcium ions } \\
\text { (mean + SD) }\end{array}$ & $\mathrm{p}^{*}$ \\
\hline \multicolumn{4}{|l|}{$\Lambda$ ge (year) } \\
\hline - $45-54$ & 25 & $9.09 \pm 0.38$ & \multirow{3}{*}{0.312} \\
\hline - $55-64$ & 21 & $8.85 \pm 0.27$ & \\
\hline - $>65$ & 17 & $9.09 \pm 0.35$ & \\
\hline \multicolumn{4}{|l|}{ BMI } \\
\hline - $<25$ & 32 & $9.09 \pm 0.30$ & \multirow{2}{*}{0.350} \\
\hline - $=25$ & 31 & $9.00 \pm 0.37$ & \\
\hline \multicolumn{4}{|l|}{ Menopausal status } \\
\hline - Perimenopause & 21 & $9.08 \pm 0.39$ & \multirow{2}{*}{0.526} \\
\hline - Postmenopause & 42 & $9.03 \pm 0.31$ & \\
\hline \multicolumn{4}{|l|}{ History of fracture } \\
\hline - Yes & 4 & $8.98 \pm 0.26$ & \multirow{2}{*}{0.695} \\
\hline - No & 59 & $9.05 \pm 0.35$ & \\
\hline \multicolumn{4}{|l|}{ Milk consumption } \\
\hline - Never & 59 & $9.06 \pm 0.34$ & \multirow{2}{*}{0.214} \\
\hline - Some time - frequent & 4 & $8.84 \pm 0.22$ & \\
\hline \multicolumn{4}{|l|}{ Calcium suplement } \\
\hline - Never & 38 & $9.01 \pm 0.37$ & \multirow{2}{*}{0.94} \\
\hline - Some time - frequent & 25 & $9.10 \perp 0.29$ & \\
\hline \multicolumn{4}{|l|}{ Corticosteroid consumption } \\
\hline - Yes & 4 & $9.00 \pm 0.28$ & \multirow{2}{*}{0.831} \\
\hline - No & 59 & $9.04 \pm 0.35$ & \\
\hline \multicolumn{4}{|l|}{ Physical activities } \\
\hline - Mild & 20 & $9.01 \pm 0.31$ & \\
\hline - Moderate-vigorous & 43 & $9.06 \pm 0.35$ & 0.624 \\
\hline
\end{tabular}

* Une way Anova (signiflcant alfjerent if $p<v . v \mathrm{U})$ 
TABLE 6. Mean of UCa/UCr ratio based on the characteristics of subjects

\begin{tabular}{|c|c|c|c|}
\hline Variables & $\mathrm{n}=63$ & $\begin{array}{c}\mathrm{UCa} / \mathrm{UCr} \\
(\text { mean } \pm \mathrm{SD})\end{array}$ & $\mathrm{p}^{*}$ \\
\hline \multicolumn{4}{|l|}{ Age (year) } \\
\hline - $45-54$ & 25 & $0.07 \pm 0.04$ & \multirow{3}{*}{0.180} \\
\hline - $55-64$ & 21 & $0.10 \pm 0.06$ & \\
\hline - $>65$ & 17 & $0.08 \pm 0.05$ & \\
\hline \multicolumn{4}{|l|}{ BMI } \\
\hline - $<25$ & 32 & $0.09 \pm 0.05$ & \multirow{2}{*}{0.669} \\
\hline - $=25$ & 31 & $0.08 \pm 0.05$ & \\
\hline \multicolumn{4}{|l|}{ Menopausal status } \\
\hline - Perimenopause & 21 & $0.08 \pm 0.04$ & \multirow{2}{*}{0.337} \\
\hline - Postmenopause & 42 & $0.09 \pm 0.04$ & \\
\hline \multicolumn{4}{|l|}{ History of fracture } \\
\hline - Yes & 4 & $0.09 \pm 0.07$ & \multirow{2}{*}{0.871} \\
\hline - No & 59 & $0.08 \pm 0.05$ & \\
\hline \multicolumn{4}{|l|}{ Milk consumption } \\
\hline - Never & 59 & $0.08 \pm 0.05$ & \multirow{2}{*}{0.712} \\
\hline - Some time - frequent & 4 & $0.07 \pm 0.05$ & \\
\hline \multicolumn{4}{|l|}{ Calcium suplement } \\
\hline - Never & 38 & $0.08 \pm 0.05$ & \multirow{2}{*}{0.405} \\
\hline - Some time - frequent & 25 & $0.09 \pm 0.05$ & \\
\hline \multicolumn{4}{|l|}{ Corticosteroid consumption } \\
\hline - Yes & 4 & $0.12 \pm 0.07$ & \multirow{2}{*}{0.200} \\
\hline - No & 59 & $0.09 \pm 0.05$ & \\
\hline \multicolumn{4}{|l|}{ Physical activities } \\
\hline - $\quad$ Mild & 20 & $0.09 \pm 0.05$ & \multirow{2}{*}{0.308} \\
\hline - Moderate-vigorous & 43 & $0.08 \pm 0.05$ & \\
\hline
\end{tabular}

Moreover, no significant difference was also observed in the mean serum calcium ions levels and the ratio of $\mathrm{UCa} / \mathrm{UCr}$ based on the osteoporosis diagnostic category ( $>0.05$ ) as presented in TABLE 7 .

TABLE 7. Mean of serum calcium ions and $\mathrm{UCa} / \mathrm{UCr}$ ratio based on osteoporosis diagnostic category

\begin{tabular}{lcccc}
\hline Variables & $\begin{array}{c}\text { Nonnal } \\
(\mathrm{n}=21)\end{array}$ & $\begin{array}{c}\text { Osteoponia } \\
(\mathrm{n}=22)\end{array}$ & $\begin{array}{c}\text { Osteoporosis } \\
(\mathrm{n}=20)\end{array}$ & $\mathrm{P}^{*}$ \\
\hline Serum calcium ions $(\mathrm{mg} / \mathrm{dL})$ & $8.96 \pm 0.32$ & $9.15 \pm 0.35$ & $9.03 \pm 0.34$ & 0.174 \\
$\mathrm{UCa} / \mathrm{UCr}$ ratio & $0.07 \pm 0.05$ & $0.08 \pm 0.05$ & $0.10 \pm 0.06$ & 0.225 \\
\hline
\end{tabular}




\section{Correlation between serum calcium ions or $\mathrm{UCa} / \mathrm{UCr}$ ratio and $\mathrm{BMD}$}

The correlation between serum calcium ions levels and $\mathrm{BMD}$ and between $\mathrm{UCa} / \mathrm{UCr}$ ratio and BMD are presented in TABLE 8. No significant correlation was observed between serum calcium ions level and BMB $(r=-0.145$, $\mathrm{p}=0.258$ ), however weak significant negative correlation was observed between $\mathrm{UCa} / \mathrm{UCr}$ ratio and $\operatorname{BMD}(r=-0.310, p=0.013)$.

TABLE 8. Correlation between serum calcium ions levels or $\mathrm{UCa} / \mathrm{UCr}$ ratio and $\mathrm{BMD}$

\begin{tabular}{lcc}
\hline Variables & $\mathrm{r}$ & $\mathrm{p}$ \\
\hline $\begin{array}{l}\text { Serum calcium ions versus } \\
\text { BMD status }\end{array}$ & -0.145 & 0.258 \\
$\begin{array}{l}\mathrm{UCa} / \mathrm{UCr} \text { ratio versus BMD } \\
\text { status }\end{array}$ & -0.310 & $0.013^{*}$ \\
\hline Pearson correlation test (significant different if $p<0.05$ )
\end{tabular}

Further analysis showed that no correlation was observed between serum calcium ions levels and lumbar BMD ( $\mathrm{r}=0.036, \mathrm{p}=0.778)$, whereas the ratio of $\mathrm{UCa} / \mathrm{UCr}$ showed a moderate negative correlation with lumbar BMD ( $\mathrm{r}=-0.414, \mathrm{p}=0.001)$. The correlation between the ratio of $\mathrm{UCa} / \mathrm{UCr}$ and lumbar BMD was stronger than that between the ratio of $\mathrm{UCa} /$ $\mathrm{UCr}$ and $\mathrm{BMD}(\mathrm{r}=-0.414$ vs. $\mathrm{r}=-0.310)$.

TABLE 9. Correlation between serum calcium ions levels or $\mathrm{UCa} / \mathrm{UCr}$ ratio and lumbar BMD

\begin{tabular}{lcc}
\hline Variables & $\mathrm{r}$ & $\mathrm{p}$ \\
\hline $\begin{array}{l}\text { Serum calcium ions versus } \\
\text { lumbar BMD }\end{array}$ & 0.036 & 0.778 \\
$\begin{array}{l}\mathrm{UCa} / \mathrm{UCr} \text { ratio versus lumbar } \\
\text { BMD }\end{array}$ & 0.414 & $0.001^{*}$ \\
\hline
\end{tabular}

* Pearson correlation test (significant different if $p<0.05$ )

\section{DISCUSSION}

This study showed that age, BMI and menopausal status were significantly associated with osteroporosis status subjects, whereas history of fracture, milk consumption, calcium suplement, corticosteroid consumption and physical activities were not associated with osteoporosis status in perimenopause and postmenopause women. The results are consistent with previous studies. ${ }^{2,12}$ Bone mass density has changed with age both in men and women. In the beginning, the process of bone remodeling is in balance or showed a surplus and no reduction in bone mass. However, as humans get older, the bone formation process becomes inadequate, resulting in decreased bone mass. In women, this process occurs from the third decade of human life or several years before menopause. ${ }^{13,14}$

This study also showed that no significantly difference was observed in serum calcium ions levels and in the $\mathrm{UCa} / \mathrm{UCr}$ ratio based on the risk factors osteoporosis namely age, BMI, menopausal status, history of fracture, milk consumption, calcium supplements, and corticosteroid consumption as well as physical activities. These results are consistent with previous studies conducted by George et al. that reported no significant difference in serum calcium levels between subjects with low BMD and normal BMD. ${ }^{15}$ The concentration of calcium ions in extracellular fluid is always maintained in contant state through calcium homeostatis mechanism. The most important hormones for maintaining calcium levels in the body are parathyroid hormone (PTH) and 1,25dihydroxyvitamin $\mathrm{D}$ (the active form of vitamin D) and calcitonin. ${ }^{9}$ The major regulator is $\mathrm{PTH}$, which is part of a negative feedback loop to maintain serum calcium ions. Secretion of PTH secretion is stimulated by hypocalcemia. Conversely, when serum calcium ions is too 
high. ${ }^{9,16}$ This may underlie the absence of difference of serum calcium ions levels in the normal bone density, osteopenia and osteoporosis.

The mean $\mathrm{UCa} / \mathrm{UCr}$ ratio increases along with the decrease of BMD. The mean $\mathrm{UCa} / \mathrm{UCr}$ ratio was higher in both osteopenia dan osteoporosis groups compare to normal group, however it was not significantly different. Previous studies showed that the increase of $\mathrm{UCa} / \mathrm{UCr}$ ratio was paralel with the increase of the severity of osteoporosis. Urinary calcium levels of postmenopausal women with osteoporosis was hingher than those without osteoporosis. ${ }^{16}$ Another study also showed that the mean $\mathrm{UCa} / \mathrm{UCr}$ ratio of postmenopausal women with osteoporosis was higher than those without osteoporosis. Moreover, the mean UCa/ UCr ratio of postmenopausal women was higher than pramenopausal women. ${ }^{17}$ Perimenopause and postmenopause are associated with the decrease in estrogen levels in the body that leads to the decrease of urinary calcium resoption in the kidney. ${ }^{18}$

In this study, no correlation was observed between serum calcium ions levels and BMD or lumbar BMD, whereas the ratio of $\mathrm{UCa} / \mathrm{UCr}$ showed a weak negative correlation with BMD and a moderate negative correlation with lumbar BMD. This results are consistent with those previous studies. ${ }^{19-22}$ Ratio of $\mathrm{UCa} / \mathrm{UCr}$ is a biochemical marker that is used at an early stage to assess bone metabolism. ${ }^{23}$ The increase of urinary calcium excretion and calcium malabsorption may be a predictor of low BMD in postmenopausal women, ${ }^{24}$ and may indicate an increase in bone resorption by osteoclasts. ${ }^{11}$

\section{CONCLUSION}

In conclusion, there is no correlation between serum calcium ions level and BMD, however there is a weak negative correlation between the $\mathrm{UCa} / \mathrm{UCr}$ ratio and $\mathrm{BMD}$ in perimenopause and postmenopause women. Ratio of $\mathrm{UCa} / \mathrm{UCr}$ can be considered as biochemical markers in osteoporosis diagnosing in subject with normal renal function. Further study should be conducted to evaluate changes in other biochemical markers with the decrease of BMD.

\section{ACKNOWLEDGEMENTS}

Authors would like to thank Head of Department of Clinical Pathology as well as Head of Department of Radiology, Universitas Gadjah Mada/Dr. Sardjito General Hospital, Yogyakarta for their support in this study. We would also like to thank all subjects who willing to participate in this study.

\section{REFERENCES}

1. Menteri Kesehatan Republik Indonesia. Keputusan Menteri Kesehatan Republik Indonesia Nomor 1142/MENKES/SK/XII/2008 Tentang pedoman pengendalian osteoporosis. Jakarta: Kepmenkes RI, 2008.

2. Stabler CAH. Osteoporosis from pathophysiology to treatment. Washington: AACC Press. 2004.

3. Nelson HD, Helfand M, Woolf SH, Allan J. Screening for postmenopausal osteoporosis: a review of the evidence for the US preventive services task force. Ann Intern Med 2002;137(6):529-41.

4. Chesnut III CH, Skag A, Christiansen C, Recker $\mathrm{R}$, Stakkestad JA, Hoiseth A, et al. Effects of oral ibandronate administered daily or intermittently on fracture risk in postmenopausal osteoporosis. J Bone Miner Res 2004;19(8):1241-9.

5. Seibel JM. Biochemical markers of bone turnover part I: biochemistry and variability. Clin Biochem Rev 2005; 26(4):97-122.

6. Thomakos N, Liakakos T. Diagnostic methods in osteoporosis. Arch Hellenic Med 2000; 17(2):146-51.

7. Calvo MS, Eyre DR, Gundberg CM. Molecular basis and clinical application of biological markers of bone turnover. Endocr Rev 1996; 17(4):33368 . 
8. Lewandrowski K. Clinical chemistry. Philadelphia: Lippincott Williams and Wilkins, 2002.

9. Guyton AC, Hall JE. Buku ajar fisiologi kedokteran, edisi 11. Jakarta: Penerbit Buku Kedokteran EGC, 2008.

10. Nicoll D, McPhee SJ, Pignone M, Lu CM. Pocket guide to diagnostic Test, $5^{\text {th }}$ edition, New York: McGraw-Hill, 2008.

11. Burtis CA, Ashwood ER, Bruns DE. Tietz textbook of clinical chemistry and molecular diagnostics, $4^{\text {th }}$ Edition, Philadelphia: Saunders Elsevier, 2006.

12. Rudiansyah M, Kertia N, Achadiyono DN, Probosuseno, Purnomo S. Hubungan roboh dengan bone mass densitydi. Klinik Lansia RSUP Dr. Sardjito Yogyakarta. Berkala Kesehatan Klinik 2007; 8(2):82-88.

13. Seeman E. Invite review: pathogenesis of osteoporosis. J Appl Physiol. 2003; 95(5):214251.

14. Warming L, Hassager C, Christiansen C. Changes in bone mineral density with age in men and women: a longitudinal study. Osteoporosis Int 2002; 13(2):105-12.

15. George J, Ganesh HK, Acharya S, Bandgar TR, Shivane V, Karvat A, et al. Bone mineral density and disorders of mineral metabolism in chronic liver disease. World J Gastroenterol 2009; 15(28):3516-22.

16. Cohen AJ, Roe FJC. Review of risk factors for osteoporosis with particular reference to a possible aetiological role of dietary salt. Food Chem Toxicol 2000; 38: 237-53.
17. Nordin BE, Need AG, Morris HA, Horowitz M. The nature and significance of the relationship between urinary sodium and urinary calcium in women. J Nutr 1993; 123(9):1615-22.

18. Väänänen HK, Härkönen PL. Estrogen and bone metabolism. Maturitas 1996; 23(Suppl):S65-9.

19. Tanzil Y. Hubungan kadar kalsium urin dengan osteoporosis pada wanita postmenopause. [Tesis]. Yogyakarta: Program Studi Patologi Klinik, Sekolah Pasca Sarjana Universitas Gadjah Mada; 2007.

20. Lee YH, Rho YH, Choi SJ, Ji JD, Song GG. Predictors of bone mineral density and osteoporosis in patients attending a rheumatology outpatient clinic. Rheumatol Int 2003; 23(2):679.

21. Sakuma M, Endo N, Oinuma T, Hayami T, Endo E, Yazawa T, et al. Vitamin D and intact PTH status in patients with hip fracture. Osteoporos Int 2006; 17(11):1608-14.

22. Freundlich M, Alonzo E, Bellorin-Font E, Weisinger JR. Reduced bone mass in children with idiopathic hypercalciuria and in their asymptomatic mothers. Nephrol Dial Transplant 2002; 17(8):1396-401.

23. Lakatos P, Takacs I, Buki B, Nemeth J, Horvath C. Urinary calcium excretion: normal values for urinary calcium/creatinine ratio in Hungary. Orv Hetil 1997; 138(22):1405-9.

24. Holzherr ML, Retallack RT, Gutteridge DH. Calcium absorption in postmenopausal osteoporosis: Benefit of HRT plus calcitriol, but not HRT alone, in both malabsorbers and normal absorbers. Osteoporos Int 2000; 11(1):43-51. 